\title{
Coexisting Traumatic Ipsilateral Extra and Subdural Hematoma- Is It Really Common?
}

\author{
Amit Kumar Ghosh*, Rafit Barma, TN Sharma and Malay Chakrobarty \\ Calcutta University, India
}

Submission: February 21, 2017; Published: April 27, 2017

*Corresponding author: Amit Kumar Ghosh, Calcutta University, India, Tel: 033-2432-0777/0999; Email: amitghosh74@yahoo.co.in

\section{Introduction}

A 37-year old man was admitted in neurosurgical unit after 6 hours of injury with history of road traffic accident and head injury. He was hemodynamically stable. His GCS was E2M5V2. Pupil was reacting bilaterally and there was mild left sided paucity of movement. There was no other major injury (spine, abdomen, and chest, long bones were normal). CT scan of brain showed extradural hematoma, mass effect, and skull fracture (Figure 1A).

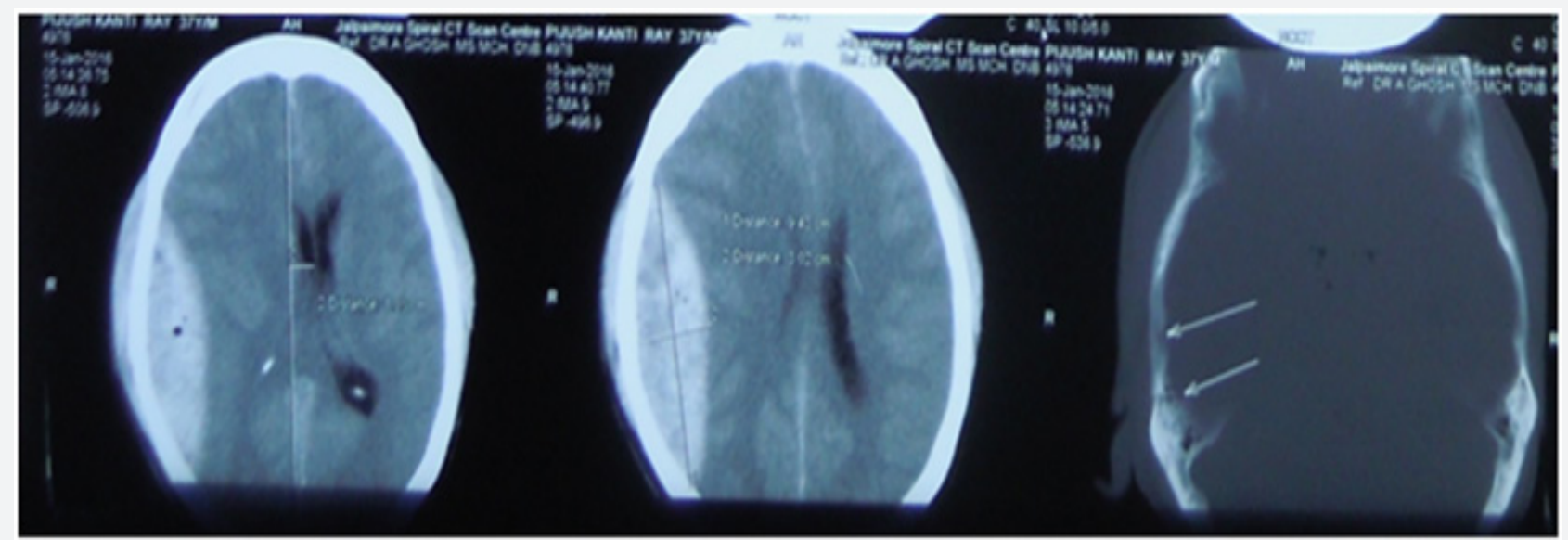

Figure 1A: CT scan of brain showed extradural hematoma, mass effect, and skull fracture.

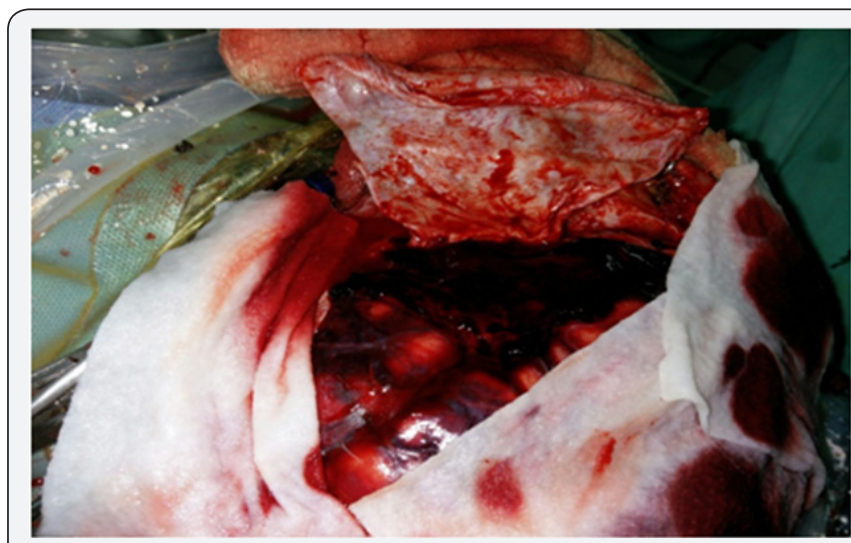

Figure 1B: Dura had been opened and subdutal hematoma was seen and evacuated.
Patient was taken for surgery after relevant preanaesthetic investigations within an hour. Right sided fronto-temporoparietal standard trauma craniectomy was done. After evacuating extradural hematoma, dura was looking bluish and tense. So, dura had been opened and subdutal hematoma was seen and evacuated (Figure 1B). After proper hemostasis, augmentation duraplasty was done and bone flap was not replaced, kept in subcutaneous pocket in anterior abdominal wall. Patient was ventilated electively for next 24 hours and then weaned off ventilator. He became conscious, was obeying commands and talking (Figure 1B)

Post-operative CT scan of brain was done which showed craniectomised skull with post-hematoma-evacuated status (Figure 2). 


\section{Open Access Journal of Neurology \& Neurosurgery}

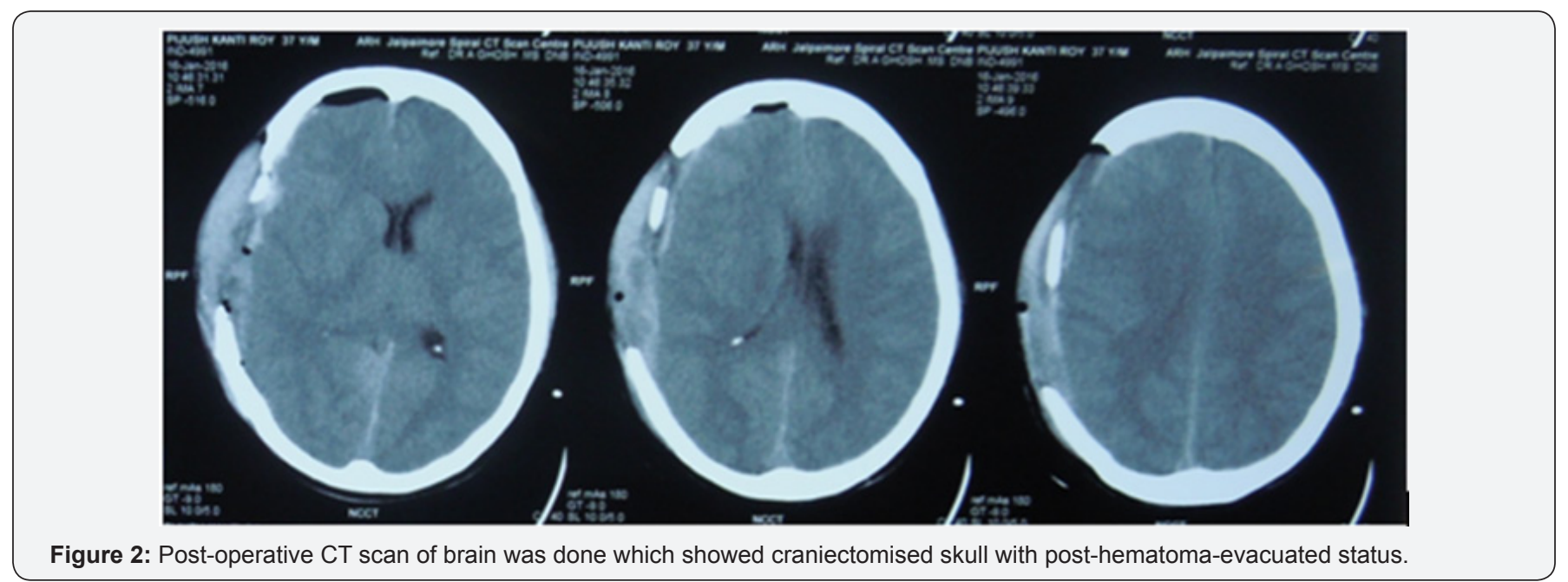

\section{Discussion}

Coexisting extradural (EDH) and subdural hematoma (SDH) in the same side is rare phenomenon. As a mechanism, it is unusual to find both EDH and SDH on the same side in patients with head trauma [1]. unless there is direct trauma. Only four case reports have been found [1-4]. More commonly, EDH and SDH happens in opposite locations. EDHs are usually coup lesions and thought to be due to direct trauma with seepage of blood from a calvarial fracture or injury to the dural arteries [4]. Acute SDH, on the other hand, is generally countercoup in location, mostly venous in origin [4], due to brain shift causing damage to the cortical bridging veins [4].

When EDH and SDH happens in the same side, the cause of the EDH is direct injury of dural artery or seepage from fracture and the SDH is also due to direct injury of cortical artery and/ or vein. Aim of surgery is evacuation of extra and subdural hematoma, secure haemostasis, and augmentation duraplasty and also it is always safe to do a standard trauma decompressive craniectomy.

\section{References}

1. Sharma AK, Diyora BD, Shah SG, Pandey AK, Mamidanna R (2005) An extradural and subdural hematoma in a neonate. Indian J Pediatr 72(3):269

2. Gupta R, Mohindra S, Verma SK (2008) Traumatic ipsilateral acute extradural and subdural hematoma. Ind J Neurotr 5: 113114

3. B Indira Devi, Arivazhagan A, Mithun G Sattur, Sastry VR Kolluri (2007) Concomitant post-traumatic craniospinal multicompartmental hematoma associated with posterior fossa extradural hematoma Case report and review of literature. Indian Journal of Neurotrauma (IJNT) 4(1): 55-57

4. Venkatesh S Madhugiri, Arivazhagan Arimappamagan, Chandramouli BA (2012) Traumatic epidural and subdural hematomas and extensive brain infarcts in a patient with pial arterio venous malformation Mechanisms underlying clinical and radiological findings. Asian J Neurosurg Oct-Dec 7(4): 210-213.

\section{Your next submission with Juniper Publishers} will reach you the below assets

- Quality Editorial service

- Swift Peer Review

- Reprints availability

- E-prints Service

- Manuscript Podcast for convenient understanding

- Global attainment for your research

- Manuscript accessibility in different formats ( Pdf, E-pub, Full Text, Audio)

- Unceasing customer service

Track the below URL for one-step submission https://juniperpublishers.com/online-submission.php 